\title{
Prevalence and Predisposing Factors of Pediculosis Capitis on Elementary School Students at Jatinangor
}

\author{
Arani Karimah, ${ }^{1}$ Risa Miliawati Nurul Hidayah, ${ }^{2}$ Anisah Dahlan ${ }^{3}$ \\ ${ }^{1}$ Faculty of Medicine Universitas Padjadjaran, ${ }^{2}$ Department of Dermatovenerology Faculty of \\ Medicine Universitas Padjadjaran/Dr. Hasan Sadikin General Hospital Bandung, ${ }^{3}$ Department of \\ Biochemistry Faculty of Medicine Universitas Padjadjaran
}

\begin{abstract}
Background: Pediculosis capitis is a lice infestation on scalp with high prevalence on the age of elementary school students. It is one of neglected diseases. Predisposing factors such as hair type and length, self higienities, and sosioeconomic can influence prevalence of pediculosis capitis. The aim of the study was to reveal pediculosis capitis prevalence and its predisposing factors on elementary school students at Jatinangor.

Methods: This study used cross-sectional descriptive method which conducted in September 2014 at Jatinangor. The study subjects were elementary school students graded 1 to 6 taken from two elementary schools by multistage random sampling technique. Data was presented in a table.

Results: The prevalence of pediculosis capitis from 123 study subjects was $55.3 \%$. The prevalence found on girls (81.3\%), students with long hair (76.9\%), students with curly hair (52.9\%), students of third grade $(66.7 \%)$, students with washing hair three times or more in a week (59.3\%), students with mothers only graduated from elementary school $(60 \%)$, students parents with income less than one million rupiah $(63.3 \%)$, students staying with four or more persons in the same house $(56.3 \%)$, and students with having previous this disease $(60.2 \%)$.

Conclusions: Pediculosis capitis prevalence on elementary school students is quite high. The prevalence based on subject characteristics and sosioeconomic is suitable with previous studies. [AM]:2016;3(2):2548]
\end{abstract}

Keywords: Elementary schools, pediculosis capitis, predisposing factors, prevalence

\section{Introduction}

Pediculus var.capitis is one of ectoparasite obligate that manifest on scalp..$^{1-2}$ This parasite has no swing, but can transmit directly through direct contact with infected person, or indirectly through equipment likes comb, hair accessories, and clothes. ${ }^{3}$ More frequent pediculosis capitis affected to 3-11 years old children with highest incidence on elementary school students. ${ }^{3,4}$ Twenty five percent of elementary school students in worldwide infected by Pediculus var.capitis. ${ }^{2}$

Some studies that have been conducted in some countries, reported that there are many predisposing factors such as gender, class grade, hair length, hair type, hair wash frequency, parents education, parents income, students who stay with four or more persons in the same house, and students who have previous this disease influence the prevalence of pediculosis capitis. ${ }^{2,3,5}$ The data about spreading of pediculosis capitis in Indonesia is still limited. Thus, the aim of this study was to determine prevalence of pediculosis capitis and its predisposing factors on elementary school students at Jatinangor.

\section{Methods}

This was a cross-sectional descriptive study on elementary school students at Jatinangor in the period of September 2014. This study has got permission from Health Research Ethics Committee Faculty of Medicine Universitas Padjadjaran. Population of this study were elementary school students at Jatinangor. Samples of this study was selected

Correspondence: Arani Karimah, Faculty of Medicine, Universitas Padjadjaran, Jalan Raya Bandung-Sumedang Km.21, Jatinangor, Sumedang, Indonesia, Phone: +628562081408, Email: aranikarimah@gmail.com 
using multiple random sampling technique. Therefore, elementary school was selected through cluster random sampling. Two elementary schools that have been selected are Mekarsari and Cikopo II elementary schools. While, 123 students was selected through simple random sampling from grade 1 to 6 . Inclusion criteria were students who wanted to involve in this study and who had complete personal and family database. Exclusion criteria were students who have incomplete personal and family database.

The subject was examined by history taking and physical examination. History taking was performed to identify symptoms in subject which lead to Pediculus var.capitis infestation. In addition, physical examination was done by doctor and researcher through visual examination using fine-tooth combing. History taking and physical examination results were recorded on medical record. The presence of eggs, larva, or adult Pediculus var.capitis indicated positive result. Subject with positive results were treated with Hexachlorocyclohexane $0.5 \%$.

Data was presented in a table form. The pediculosis capitis prevalence and its predisposing factors was determined from grade 1 to 6 students

\section{Results}

One hundred and twenty three students of grade 1 to 6 from two elementary schools at Jatinangor were involved in this study. Pediculosis capitis has been found on $55.3 \%$ study subject (Table 1).

Prevalence of pediculosis capitis was higher on girls. Besides that, the highest prevalence were among $3^{\text {rd }}$ grade students and the lowest
Table 1 Prevalence of Pediculosis Capitis

\begin{tabular}{lcc}
\hline \multicolumn{1}{c}{ Pediculosis capitis } & N & \% \\
\hline Positive & 68 & 55.3 \\
Negative & 55 & 44.7 \\
Total & 123 & 100 \\
\hline
\end{tabular}

were among $5^{\text {th }}$ grade students (Table 2).

Prevalence of pediculosis capitis was higher on students who has long hair, students who has curly hair, students who wash hair three times or more a week, and students who had history of pediculosis capitis (Table 3 ).

Prevalence of pediculosis capitis was higher on students whose mother graduated from elementary school, parents income is lesser than one million rupiah and students who stay with four people or more in one house (Table 4).

\section{Discussion}

In this study, prevalence of pediculosis capitis among elementary school students were $55.3 \%$. The high prevalence of pediculosis capitis was indicated by some studies such as in in Kelantan, Malaysia ${ }^{2}$ with prevalence $35 \%, 28.48 \%$ in Thailand $3,49 \%$ in Penang, Malaysia ${ }^{7}$, and $26 \%$ in Dera Ismail Khan ${ }^{8}$. Furthermore, some previous studies indicated that low on prevalence of pediculosis capitis i.e in $\operatorname{Iran}^{5}$ 8.1\%, in France ${ }^{9} 3.3 \%$, and in Peru ${ }^{10}$ $9.1 \%$. Prevalence of pediculosis capitis is found higher $(81.2 \%)$ on girl. It is caused by girls habit that interact longer and closer with each other, thus increases risk of transmission for Pediculus var.capitis transmission. . $^{2,3}$ Moreover, study by Rassami and Soonwera ${ }^{3}$

Table 2 Prevalence of Pediculosis Capitis Based on Subject Characteristics

\begin{tabular}{lcccc}
\hline \multicolumn{2}{c}{ Subject Characteristics } & \multicolumn{2}{c}{ Pediculosis capitis } & \multirow{2}{*}{ Total } \\
\cline { 2 - 3 } & & Positive $\mathbf{n ( \% )}$ & Negative $\mathbf{n ( \% )}$ & \\
\hline Gender & Girl & $52(81.2)$ & $12(18.8)$ & 64 \\
& Boy & $16(27.1)$ & $43(72.9)$ & 59 \\
Grade & 1 & $14(63.6)$ & $8(36.4)$ & 22 \\
& 2 & $14(56)$ & $11(44)$ & 25 \\
& 3 & $14(66.7)$ & $7(33.3)$ & 21 \\
& 4 & $9(50)$ & $9(50)$ & 18 \\
& 5 & $9(42.9)$ & $12(57.1)$ & 21 \\
& 6 & $8(50)$ & $8(50)$ & 16 \\
\hline
\end{tabular}


Table 3 Prevalence of Pediculosis Capitis Based on Risk Factors

\begin{tabular}{|c|c|c|c|c|}
\hline \multicolumn{2}{|c|}{ Risk Factors } & \multicolumn{2}{|c|}{ Pediculosis capitis } & \multirow{3}{*}{$\frac{\text { Tota }}{26}$} \\
\hline & & \multirow{2}{*}{$\begin{array}{c}\text { Positive n(\%) } \\
20(76.9)\end{array}$} & \multirow{2}{*}{$\frac{\text { Negative } \mathbf{n}(\%)}{6(23.1)}$} & \\
\hline Hair length & Long & & & \\
\hline \multirow{3}{*}{ Hair type } & Short & $48(49.5)$ & $49(50.5)$ & 97 \\
\hline & Straight & 55 (52.9) & $49(47.1)$ & 104 \\
\hline & Curly & $13(68.4)$ & $6(31.6)$ & 19 \\
\hline \multirow{2}{*}{$\begin{array}{l}\text { Hair wash frequency } \\
\text { in one week }\end{array}$} & $\geq 3 x$ & $48(59.3)$ & $33(40.7)$ & 81 \\
\hline & $\leq 2 \mathrm{x}$ & $20(47.6)$ & $22(52.4)$ & 42 \\
\hline \multirow[t]{2}{*}{ Had previous disease } & Yes & $56(60.2)$ & 37 (39.8) & 93 \\
\hline & No & $12(40)$ & $18(60)$ & 30 \\
\hline
\end{tabular}

proved that girls are 40 times more commonly infected by Pediculus var.capitis than boy.

Students with long hair had prevalence for pediculosis capitis infection higher (76.9\%) than students with short hair (49.5\%). This was caused by longer hair provides warm and humid environment which favors the living Pediculus humanus var.capitis. ${ }^{1}$ In addition, study by Bachok et al. ${ }^{2}$ showed that elementary school students whose hair below shoulder has higher prevalence $(62.8 \%)$ than whose hair above the shoulder $(16.1 \%)$.

In this study, prevalence of pediculosis capitis on curly hair students were $68.4 \%$, while student with straight hair had lower prevalence $(52.9 \%)$. Results obtained from this study was almost similar to the previous study by Bachok et al. ${ }^{2}$ study where prevalence were higher on students with curly hair (57.1\%). Moreover, student by Manrique et al. ${ }^{11}$ showed that students with straight hair had higher prevalence (34\%) than students with curly hair $(25 \%)$.

The highest prevalence of pediculosis capitis was on $3^{\text {rd }}$ grade students $(66.7 \%)$. The lowest prevalence was on 5 th grade students (42.9\%). Rukke et al. ${ }^{2}$ research showed that the highest prevalence of pediculosis capitis is among students age $\leq 15$ years old. Moreover, study by Manrique et al. ${ }^{11}$ proved that students $\leq 9$ years old $(37 \%)$ students on $3^{\text {rd }}$ grade or under $3^{\text {rd }}$ grade $(37.6 \%)$ has higher prevalence.

According to $\mathrm{Sim}$ et al. ${ }^{6}$, subject who wash hair less than three times $(0.23 \%)$ has higher prevalence than who wash hair three or more in a week $(0.12 \%)$. Thus, washing hair three times or more in a week decreases the prevalence. In this study prevalence of pediculosis capitis was higher among students who wash hair three times or more in a week

Table 4 Prevalence of Pediculosis Capitis Based on Sosioeconomic

\begin{tabular}{|c|c|c|c|c|}
\hline \multirow{2}{*}{\multicolumn{2}{|c|}{ Sosioeconomic }} & \multirow{2}{*}{\multicolumn{2}{|c|}{ Pediculosis capitis }} & \multirow{3}{*}{$\begin{array}{c}\text { Total } \\
20\end{array}$} \\
\hline & & & & \\
\hline Mother education level & Elementary School & $\begin{array}{c}\text { Positive } \mathbf{n}(\%) \\
12(60)\end{array}$ & $\frac{\text { Negative } \mathbf{n}(\%)}{8(40)}$ & \\
\hline \multirow{6}{*}{ Parents income } & Junior High School & $24(51.1)$ & $23(48.9)$ & 47 \\
\hline & Senior High School & $28(59.6)$ & $19(40.4)$ & 47 \\
\hline & University & $4(44.4)$ & $5(56.6)$ & 9 \\
\hline & $<$ Rp. $1.000 .000,00$ & $21(60)$ & $14(40)$ & 35 \\
\hline & $\begin{array}{l}\text { Rp 1.000.000,00-Rp } \\
3.000 .000,00\end{array}$ & $42(54.5)$ & $35(45.5)$ & 77 \\
\hline & $>$ Rp. $3.000 .000,00$ & $5(45.5)$ & $6(54.5)$ & 11 \\
\hline \multirow{2}{*}{$\begin{array}{l}\text { Number of family } \\
\text { memberwho stay } \\
\text { in the same house }\end{array}$} & $\geq 4$ & $63(56.3)$ & $49(43.7)$ & 112 \\
\hline & $<4$ & $5(45.5)$ & $6(54.5)$ & 11 \\
\hline
\end{tabular}


$(59.3 \%)$ than students who wash hair less than three times a week (47.6\%).

Students whose mother graduated from elementary school had the highest prevalence, while those whose mother graduated from university had the lowest prevalence. Therefore, parents education level, especially mother, influenced students personal hygine. Study in $\operatorname{Iran}^{5}$ indicated that highest prevalence of pediculosis capitis (2.3\%) were among students whose mother graduated from elementary schools and junior high schools. Besides, students whose mother graduated from university had the lowest prevalence $(0.2 \%)$.

Parents income influenced prevalence of pediculosis capitis infection among students. It was caused by poverty, lack of knowledge about disease, lack of parents attention to

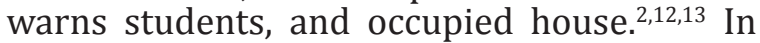
this study, the highest prevalence of pediculosis capitis among student whose parents income was less than one million rupiah (60\%). This income was low or under the average in Indonesia. Study conducted in Mexico ${ }^{11}$ showed that prevalence of pediculosis capitis was higher $(56 \%)$ on student whose parents income is less than four thousand dollar than students whose parents income four thousand dollar or more (15.6\%).

Number of family member who stays in the same house also influences prevalence of pediculosis capitis. Prevalence will be higher on big family, especially on students who has many elementary school students, because close contact with each other and density of the house more facilitated transmission of Pediculus humanus var.capitis. ${ }^{2,12,13}$ In this study, prevalence of pediculosis capitis was higher $(56.3 \%)$ on students who stay with four persons or more in one house than students who stay with less than four persons $(4 ., 5 \%)$. Study in Iran $^{5}$ in 2008 showed that prevalence of pediculosis capitis was higher (3.51\%) on students who stay with more than ten people than students who stay with five until ten people $(2.28 \%)$ and those who stay with less than five people in one house $(0.68 \%)$. In addition, study by Lesshafft et al. ${ }^{10}$ proved that prevalence is higher among students who stay with more than four persons than those who stay with less than four persons in one house.

Prevalence of pediculosis capitis was also higher among students who had previous history of pediculosis capitis infection (60.2\%) than who do not have past history (40\%). This study was similar to the study by MotovaliEmami et al. ${ }^{5}$ i.e which prevalence was higher on students who had history of the disease (5\%) than students who do not had history of the disease $(0,9 \%)$.

It can be concluded that prevalence of pediculosis capitis on elementary school students is quite high and prevalence of pediculosis capitis and its predisposing factors are suitable with previous studies.

One of the limitation from this study is difficulty in interviewing the students about their personal identity, because not all students were accompanied by their parents. In addition, the limited student data which is related to predisposing factors on administration, exlude students from this study. This study was not an analitical statistic. Thus, the correlation between pediculosis capitis prevalence and its predisposing factor can not be determined.

For other researchers, it is better to conduct study about the existence of pediculosis capitis prevalence and predisposing factors in other parts of Indonesia. Furthermore, it is required to give routine counseling about pediculosis capitis to all the students, teachers, and parents. Thus, they have more knowledge about pediculosis capitis and its predisposing factors. Therefore, risk of transmission can be prevented. Finally, since the prevalence of pediculosis capitis is considerable, public health service committee and communit'ss attention is needed to eradicate pediculosis capitis infection.

\section{References}

1. Canadian Paediatric Society. Head lice infestation: a clinical update. Paediatr Child Health. 2008;13(8):692-6.

2. Bachok N, Nordin RB, Awang CW, Ibrahim NA, Naing L. Prevalence and associated factors of head lice infestation among primary schoolchildren in Kelantan, Malaysia. Southeast Asian J Trop Med Public Health. 2006;37(3):536-43.

3. Rassami W, Soonwera M. Epidemiology of pediculosis capitis among school children in the eastern area of Bangkok, Thailand. Asian Pac J Trop Biomed. 2012;2(11):9014.

4. Nutanson I, Steen CJ, Schwartz RA, Janniger CK. Pediculus humanus capitis: an update. Acta Dermatovenerol Alp Pannonica Adriat. 2008;17(4):147-54.

5. Motovali-Emami M, Alfatoonian MR, Fekri A, Yazdi M. Epidemiological aspects of pediculosis capitis and treatment evaluation in primary school children in 
Iran. Pak J Biol Sci. 2008;11(2):260-4.

6. Sim S, Lee WA, Yu JR, Lee SH, Oh SY, Seo $M$, et al. Risk factors associated with head louse infestation in Korea. Korean J Parasitol. 2011;49(1):95-8.

7. Muhammad Zayyid M, Sayyidatul Saadah R, Adil AR, Rohela M, Jamaiah I. Prevalence of scabies and head lice among children in a welfare home in Pulau Pinang, Malaysia. Trop Biomed. 2010;27(3):442-6.

8. Ali N, Ramzan F. Head lice infestation in school children at Dera Ismail Khan. Pakistan J Zool. 2004;36(4):273-80.

9. Durand R, Millard B, Bouges-Michel CB, Bruel C, Bouvresse S, Izri A. Detection of pyrethroid resistance gene in head lice in school children from Bobigny, France. J Med Entomol. 2007;44(5):796-8.

10. Lesshafft H, Baier A, Guerra H, Terashima
A, Feldmeier H. Prevalence and risk factors associated with pediculosis capitis in an impoverished urban community in Lima, Peru. J Glob Infect Dis. 2013;5(4):138-43.

11. Manrique P, Norma, C. J, Pilger D, Herrera $\mathrm{H}$. Prevalence of pediculosis capitis in children from a rural school in Yucatan, Mexico. Rev Inst Med Trop Sao Paulo. 2011;53(6):325-7.

12. Rukke BA, Birkemoe T, Soleng A, Lindstedt $\mathrm{HH}$, Ottesen P. Head lice prevalence among households in Norway: importance of spatial variables and individual and household characteristic. Parasitology. 2011; 138(10): 1296-304.

13. AL-Shawa RM. Pediculus capitis, infestation according to sex and social factors in Gaza Governorate. The Islamic Univ J. 2008;16(1):75-83. 